Acta vet. scand. 1984, 25, 419-424.

From the Department of Internal Medicine I, Division of Parasitology, Norwegian College of Veterinary Medicine, Oslo, Norway.

\title{
THE RACCOON DOG (NYCTEREUTES PROCYONOIDES) AS DEFINITIVE HOST FOR SARCOCYSTIS SPP. OF REINDEER (RANGIFER TARANDUS)
}

\author{
By \\ Bjørn Gjerde
}

\begin{abstract}
GJERDE, B.: The raccoon dog (Nyctereutes procyonoides) as definitive host for Sarcocystis spp. of reindeer (Rangifer tarandus). Acta vet. scand. 1984, 25, 419-424. - A raccoon dog (Nyctereutes procyonoides; Family: Canidae), was given cardiac muscle of reindeer infected with S. grueneri, and started shedding Sarcocystis sporocysts 10 days post feeding. The sporocysts measured $13.9(12.4-15.7) \times$ $10.1(9.2-11.2) \mu \mathrm{m}$, and were excreted for at least 16 days. The raccoon dog is thus an additional definitive host for S. grueneri (Yakimoff \& Sokoloff, 1934) Gjerde, 1984.

Another raccoon dog was given skeletal muscle infected with 4 species of Sarcocystis, none of which was S. grueneri. The raccoon dog started shedding Sarcocystis sporocysts on day 10 post feeding, and excreted sporocysts for at least 16 days. The sporocysts measured $14.0(12.3-15.6) \times 10.1(9.2-11.2) \mu \mathrm{m}$, and are considered to be sporocysts of S. tarandivulpes Gjerde, 1984.

This is the first record of the raccoon dog as an experimental definitive host for Sarcocystis.
\end{abstract}

S. grueneri; S. tarandivulpes.

Sarcocystis is a tissue cyst-forming eimeriid coccidian with an obligatory two-host life cycle. Herbivores and omnivores act as intermediate hosts, harbouring the encysted form of the parasite in their musculature. The definitive hosts, carnivores and man, aquire infection by ingesting mature sarcocysts, and excrete oocysts and sporocysts in their faeces after the parasite has undergone gametogony and sporogony in the lamina propria of the intestine.

Each Sarcocystis species usually infects only 1 species of intermediate host, but may be infectious to several closely related 
species of definitive hosts (Tadros \& Laarman 1982). Moreover, a single species of intermediate host may harbour several species of Sarcocystis. Thus, the reindeer has been shown to be the intermediate host for 6 species of Sarcocystis (Gjerde $1984 \mathrm{~d}$ ), 2 of which have been found to have foxes and dogs as definitive hosts (Gjerde \& Bratberg 1984, Gjerde $1984 \mathrm{c}$ ).

In the present paper another canid, the raccoon dog, is reported to be a suitable definitive host for Sarcocystis spp. of reindeer.

\section{MATERIALS AND METHODS}

Fresh musculature was obtained from adult domestic reindeer slaughtered at an abattoir in Karasjok in Finnmark county in northern Norway. The muscle tissue was kept refrigerated until used for experimental feeding or for examination for sarcocysts. Cysts were micro-isolated and classified according to their cyst wall structure as previously described (Gjerde $1984 \mathrm{a}, \mathrm{b}, \mathrm{c}, \mathrm{d}$ ).

After storage for 7 days a pooled sample $(200 \mathrm{~g})$ of cardiac muscle from 2 reindeer was given to raccoon dog $12 \mathrm{~A}$ in a single feeding. The cardiac muscle harboured numerous cysts of $S$. grueneri (cysts with no light microscopically visible cyst wall protrusions). Correspondingly, a pooled sample (300 g) of abdominal musculature from the same 2 reindeer was given to raccoon dog $10 \mathrm{C}$. The abdominal musculature harboured relatively many cysts of $S$. rangiferi, a moderate number of cysts of S. tarandi and S. tarandivulpes, and a few cysts of $\mathrm{S}$. hardangeri.

The raccoon dogs were $1 \frac{1 / 2}{2}(10 \mathrm{C})$ and $3 \frac{1}{2}$ (12A) years old, and had been born and reared at the Research Farm for Furbearing Animals, Heggedal, Norway. They had never eaten raw musculature before, and were kept individually in wire mesh cages. Their faeces were collected daily, beginning 4 days after feeding, and examined later for the presence of oocysts and sporocysts by means of a flotation technique using a $\mathrm{NaCl} / \mathrm{ZnCl}_{2}-$ solution. The faecal sampling ended on day 25 post feeding.

The size of the sporocysts was measured with an ocular micrometer.

\section{RESULTS}

In the faeces of raccoon dog $12 \mathrm{~A}$ Sarcocystis sporocysts were first detected on day 10 after the experimental feeding. Sporocysts were shed continuously for the rest of the observation 
Bjørn Gjerde: The raccoon dog (Nyctereutes procyonoides) as definitive host for Sarcocystis spp. of reindeer (Rangifer tarandus).

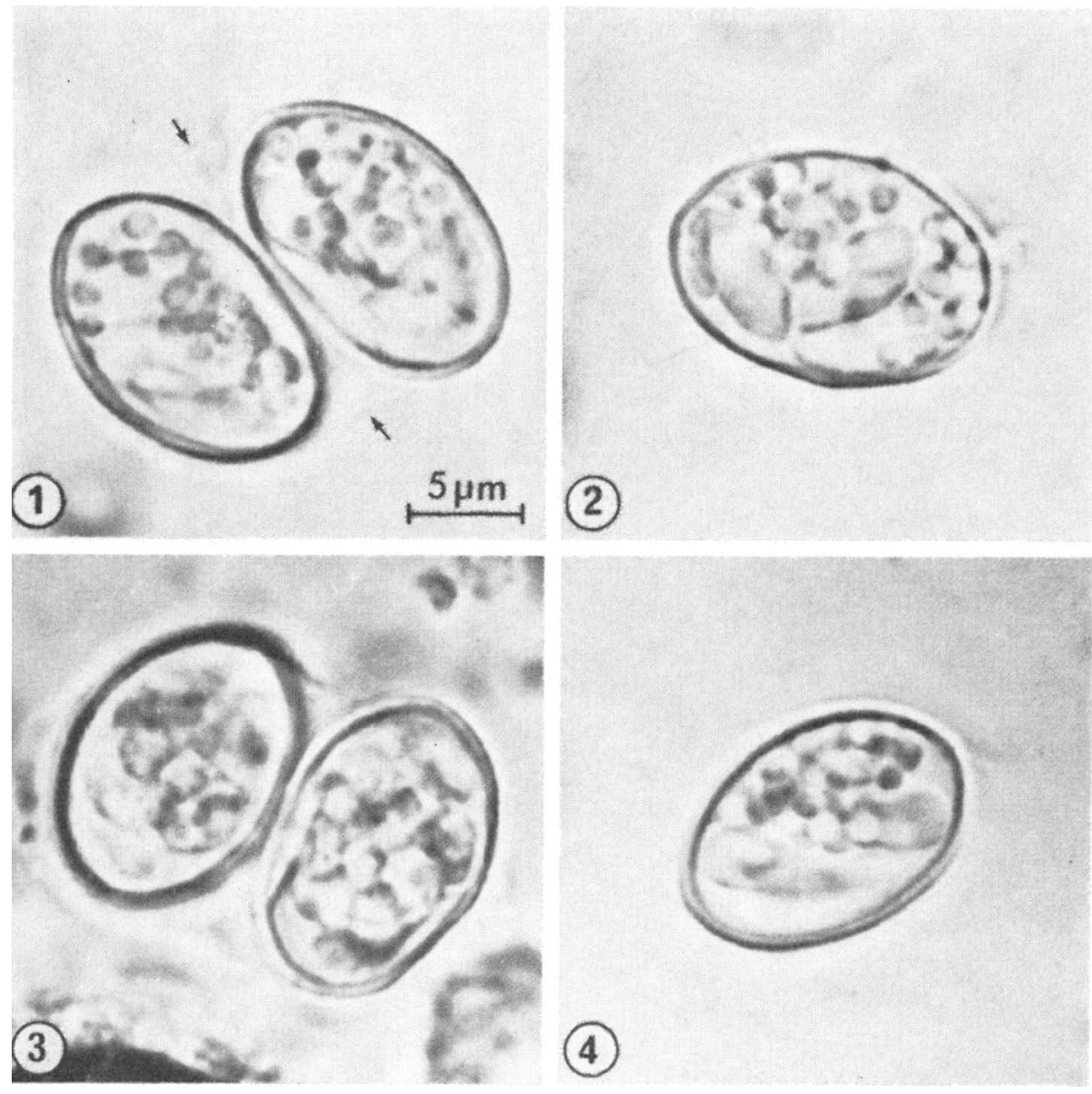

Fig u r e 1. An oocyst of S. grueneri shed by raccoon dog $12 \mathrm{~A} 13$ days after ingesting infected cardiac muscle of reindeer. Note thin oocyst wall (arrow). Unstained; $\times 2500$.

$\mathrm{F}$ ig u r e 2. A sporocyst of $\mathrm{S}$. grueneri shed by raccoon dog 12A. Unstained; $\times 2500$.

F i g u r e 3. An oocyst of Sarcocystis sp. (probably of S. tarandivulpes) shed by raccoon $\operatorname{dog} 10 \mathrm{C} 13$ days after ingesting infected skeletal muscle of reindeer. Unstained; $\times 2500$.

F ig u r e 4. A sporocyst of Sarcocystis sp. shed by raccoon dog $10 \mathrm{C}$. Unstained; $\times 2500$. 
period, i.e. for 16 days. A few Sarcocystis oocysts were also seen, mainly during the first days of patency.

The oocysts and sporocysts showed all the features characteristic for Sarcocystis. The oocysts had a very thin wall, and each oocyst contained 2 fully sporulated sporocysts (Fig. 1). The ovoid sporocysts each contained 4 elongate sporozoites and a compact or scattered granular sporocystic residuum (Fig. 2). The sporocysts measured on average $13.9 \pm 0.6(12.4-15.7) \times$ $10.1 \pm 0.4(9.2-11.2) \mu \mathrm{m} ; \mathrm{n}=180$. Their mean length to width ratio was 1.38 .

Raccoon dog 10C started shedding Sarcocystis sporocysts on day 10 post feeding, and was still passing sporocysts when the experiment ended on day 25 post infection. A few Sarcocystis oocysts were also excreted.

The sporocysts and oocysts were structurally similar to those shed by raccoon $\operatorname{dog} 12 \mathrm{~A}$ (Figs. 3 and 4 ). The sporocysts measured on average $14.0 \pm 0.7(12.3-15.6) \times 10.1 \pm 0.4(9.2-11.2)$ $\mu \mathrm{m} ; \mathrm{n}=180$. Their mean length to width ratio was 1.39 .

\section{DISCUSSION}

Several species of Sarcocystis have been found to have more than 1 species of definitive hosts (Tadros \& Laarman 1982). However, the definitive hosts have usually been closely related, i.e. belonging to the same systematic family. Thus, S. grueneri (Yakimoff \& Sokoloff, 1934) Gjerde, 1984 and S. tarandivulpes Gjerde, 1984 of the reindeer have previously been found to have dogs, and silver and blue foxes as definitive hosts (Gjerde \& Bratberg 1984, Gjerde $1984 \mathrm{c}$ ).

In the present investigation 2 canids of the species Nyctereutes procyonoides were given Sarcocystis-infected cardiac and skeletal musculature, respectively, from reindeer. Both raccoon dogs subsequently shed oocysts and sporocysts of Sarcocystis. As only cysts of $S$. grueneri were demonstrated in the cardiac muscle given to raccoon $\operatorname{dog} 12 \mathrm{~A}$, which is in accordance with previous findings (Gjerde $1984 \mathrm{a}, \mathrm{b}, \mathrm{c}$ ), the sporocysts shed by this raccoon dog are considered to be sporocysts of this species.

The sporocysts shed by raccoon $\operatorname{dog} 10 \mathrm{C}$, on the other hand, may theorethically have been sporocysts of any of the 4 Sarcocystis spp. demonstrated in the skeletal muscle used for experimental feeding. The failure to detect cysts of $S$. grueneri in 
skeletal muscle is in agreement with previous findings (Gjerde $1984 \mathrm{a}, \mathrm{b}, \mathrm{c}$ ), and this species is therefore not considered to have caused the sporocyst shedding by raccoon $\operatorname{dog} 10 \mathrm{C}$. Thus, it is likely that these sporocysts belonged to the other species with a known canid/reindeer life cycle, i.e. S. tarandivulpes. However, the definitive hosts for S. rangiferi, S. tarandi, and S. hardangeri have not yet been determined, so the possibility that some of these species also contributed to the sporocyst shedding by raccoon dog 10C cannot be completely ruled out.

The sporocysts shed by the raccoon dogs in the present investigation were about the same size as the sporocysts shed by dogs and silver and blue foxes fed muscle tissue of reindeer in previous investigations (Gjerde \& Bratberg 1984, Gjerde $1984 \mathrm{c}$, and unpublished data). Moreover, the prepatent periods of 10 days recorded from the raccoon dogs were the same as the prepatent periods recorded for $S$. grueneri and $S$. tarandivulpes in the fox (Gjerde $1984 \mathrm{c}$, and unpublished data). Taken together these facts strongly indicate that the raccoon dog is another definitive host for S. grueneri and S. tarandivulpes of reindeer.

To the author's knowledge this is the first experimental completion of the life cycle of Sarcocystis spp. in raccoon dogs. This carnivore has previously only been recorded as an intermediate host for Sarcocystis (Levine \& Ivens 1981). However, the sporocysts found by Mackinnon \& Dibb (1938) in the faeces of a raccoon $\operatorname{dog}$ in a London zoo, and considered to be sporocysts of Isospora rivolta by the authors, may have been sporocysts of Sarcocystis. Being a canid, it is likely that the raccoon dog can serve as an additional definitive host for other Sarcocystis spp. known to undergo gametogony in canine hosts.

Wild raccoon dogs have only recently been introduced into Finnmark in northern Norway (Wikan 1983), spreading from the northern Soviet Union and Finland. The small number of animals supposed to be present in the Norwegian fauna, suggests that the raccoon dog only plays a minor role in the epidemiology of Sarcocystis-infection among domestic reindeer in northern Norway. However, the present investigation has shown that the raccoon $d o g$ is a potential definitive host for Sarcocystis spp. of reindeer. Further work is needed to study the development of these Sarcocystis species in the intestine of the raccoon dog, and to determine the infectivity of sporocysts from the raccoon dog for the reindeer. 


\section{AGKNOWLEDGEMENTS}

The author thanks K. Bach-Gansmo, Karasjok, for the sampling of the musculature used in the present investigation, and the staff at the Research Farm for Furbearing Animals, Heggedal, for collecting the faecal samples from the raccoon dogs.

\section{REFERENCES}

Gjerde, B.: A light microscopic comparison of the cysts of four species of Sarcocystis infecting the domestic reindeer (Rangifer tarandus) in northern Norway. Acta vet. scand. 1984 a, 25, 195-204.

Gjerde, B.: Sarcocystis infection in wild reindeer (Rangifer tarandus) from Hardangervidda in southern Norway: With a description of the cysts of Sarcocystis hardangeri n. sp.. Acta vet. scand. $1984 \mathrm{~b}, 25,205-212$.

Gjerde, B.: The fox as definitive host for Sarcocystis sp. Gjerde, 1984 from sketal muscle of reindeer (Rangifer tarandus). With a proposal for Sarcocystis tarandivulpes $n$. sp. as replacement name. Acta vet. scand. $1984 \mathrm{c}, 25,403-410$.

Gjerde, B.: Sarcocystis hardangeri and Sarcocyystis rangi n. sp. from the domestic reindeer (Rangifer tarandus) in northern Norway. Acta vet. scand. $1984 \mathrm{~d}, 25,411-418$.

Gjerde, B. \& B. Bratberg: The domestic reindeer (Rangifer tarandus) from northern Norway as intermediate host for three species of Sarcocystis. Acta vet. scand. 1984, 25, 187-194.

Levine, N. D. \& V. Ivens: The coccidian parasites (Protozoa, Apicomplexa) of carnivores. Illinois Biological Monographs 1981, 51, $248 \mathrm{pp}$.

Macklnnon, D. L. \& M. J. Dibb: Report on intestinal protozoa of some mammals in the Zoological Gardens at Regent's Park. Proc. Zool. Soc. London 1938, 108(B), 323-345.

Tadros, W. \& J. J. Laarman: Current concepts on the biology, evolution and taxonomy of tissue cyst-forming eimeriid coccidia. Adv. Parasitol. 1982, 20, 293-468.

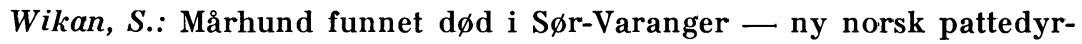
art. (Raccoon dog found dead in Sør-Varanger - a new mammalian species in Norway). Fauna 1983, 36, 103.

\section{SAMANDRAG}

Mårhund (Nyctereutes procyonoides) som endevert for Sarcocystisarter frå rein (Rangifer tarandus).

Ein mårhund (Nyctereutes procyonoides; Familie: Canidae) vart fôra med rå hjertemuskulatur frå 2 tamreinar frå Finnmark. I hjertemuskulaturen vart det berre påvist cyster av S. grueneri. Etter ein prepatentperiode på 10 dagar tok mårhunden til å skilja ut oocyster og sporocyster av Sarcocystis med avføringa. Sporocystene målte i gjennomsnitt $13.9(12.4-15.7) \times 10.1(9.2-11.2) \mu \mathrm{m}$, og vart framleis 
skilde ut då forsøket vart avslutta 25 dagar etter den eksperimentelle fôringa. På grunnlag av dessa funna reknar ein mårhund som endevert for S. grueneri (Yakimoff \& Sokoloff, 1934) Gjerde, 1984.

Ein annan mårhund vart fôra med rå bukmuskulatur frå dei same 2 reinane. Bukmuskulaturen inneheldt cyster av S. rangiferi, S. tarandi, S. tarandivulpes og S. hardangeri. Denne mårhunden tok til å skilja ut oocyster og sporocyster av Sarcocystis etter ein prepatentperiode på 10 dagar. Sporocystene målte i gjennomsnitt $14.0(12.3-15.6) \times$ $10.1(9.2-11.2) \mu \mathrm{m}$, og vart skilde ut $\mathrm{i}$ minst 16 dagar. Ein reknar det for mest sannsynleg at desse sporocystene tilhøyrer S. tarandivulpes, då det tidlegare er vist at denne arta har hund og rev (Canidae) som endevertar.

Dette er fyrste gongen mårhund vert rapportert som endevert for Sarcocystis etter eksperimentell infeksjon.

(Received July 10, 1984).

Reprints may be requested from: B. Gjerde, the Norwegian College of Veterinary Medicine, Box 8146, Dep., N-0033 Oslo 1, Norway. 